\title{
Antimicrobial peptides in echinoderm host defense
}

Chun $\mathrm{Li}^{1 *}$, Hans-Matti Blencke ${ }^{1,2}$, Tor Haug ${ }^{1,2}$, and Klara Stensvåg ${ }^{1,2 *}$

${ }^{1}$ Norwegian College of Fishery Science, Faculty of Biosciences, Fisheries and Economics,

UiT The Arctic University of Norway, Breivika, N-9037 Tromsø, Norway

${ }^{2}$ Centre for Research-based Innovation on Marine Bioactives and Drug Discovery

(MabCent-SFI), UiT The Arctic University of Norway, N-9037 Tromsø, Norway

*Corresponding authors.

E-mail address: Chun.Li@uit.no (C. Li)

Tel.: +47 776463 28; Fax: +47 77645110 .

E-mail address: Klara.Stensvag@uit.no (K. Stensvåg)

Tel.: +47 776445 12; Fax: +47 77645110 . 


\begin{abstract}
Antimicrobial peptides (AMPs) are important effector molecules in innate immunity. Here we briefly summarize characteristic traits of AMPs and their mechanisms of antimicrobial activity. Echinoderms live in a microbe-rich marine environment and are known to express a wide range of AMPs. We address two novel AMP families from coelomocytes of sea urchins: cysteine-rich AMPs (strongylocins) and heterodimeric AMPs (centrocins). These peptide families have conserved preprosequences, are present in both adults and pluteus stage larvae, have potent antimicrobial properties, and therefore appear to be important innate immune effectors. Strongylocins have a unique cysteine pattern compared to other cysteine-rich peptides, which suggests a novel AMP folding pattern. Centrocins and SdStrongylocin 2 contain brominated tryptophan residues in their native form. This review also includes AMPs isolated from other echinoderms, such as holothuroidins, fragments of beta-thymosin, and fragments of lectin (CEL-III). Echinoderm AMPs are crucial molecules for the understanding of echinoderm immunity, and their potent antimicrobial activity makes them potential precursors of novel drug leads.
\end{abstract}

\title{
Keywords
}

Echinoderms; coelomocytes; larva; innate immunity; anti-inflammatory; membrane integrity 
Antimicrobial peptides (AMPs) are widespread molecules found both in prokaryotes and eukaryotes and provide important protection to hosts against pathogens and/or environmental 'invaders'. To date, approximately 2,400 naturally isolated or synthesized AMPs have been listed in the Antimicrobial Peptide Database (APD database, http://aps.unmc.edu/AP/main.php). The majority of these AMPs are from amphibians, insects, mammals, and plants (Wang et al., 2009). There are comparatively few research activities throwing light on AMPs in echinoderms. Here, we present an overview of what is currently known about echinoderm AMPs, with a special focus on recently identified AMPs from sea urchins. Characteristics such as antimicrobial activity, peptide structure, expression profile, and biological function in echinoderms are discussed.

\section{Echinoderm host defense}

Echinoderms are deuterostome invertebrates, with a phylogenetic position closely related to chordates and hemichordates (Kondo and Akasaka, 2012). They are categorized into five classes: Crinoidea (sea lilies and feather stars), Ophiuroidea (brittle stars), Asteroidea (sea stars), Echinoidea (sea urchins, sand dollars, and sea biscuits), and Holothuroidea (sea cucumbers). These animals have a unique morphology that includes a water vascular system and a pentamerously symmetrical body shape in the adults. All living echinoderms are marine species and occupy habitats from the intertidal zone to the deep sea. These environments are rich in bacteria, fungi, viruses, and parasites, and many are potentially pathogenic to echinoderms. Echinoderms have evolved in complex means to overcome these challenges as was first illustrated from the annotation of the purple sea urchin genome (Rast et al., 2006).

Echinoderms have an innate immune system, but as all other invertebrates they lack a vertebrate-type adaptive immune system (Smith and Davidson, 1992). However, their ability to reject non-self tissues has been documented for several echinoderm species (reviewed by Smith et al. 2010 and Smith et al. 2006). Many of their immune activities occur in the 
coelomic fluid, which is a complex fluid containing minerals, proteins, and suspended cells called coelomocytes. These coelomocytes are critical immune mediators and are involved in the response against pathogens, injuries, and foreign substances (Smith et al., 2010; Smith et $a l .$, 2006). In general there are four morphologically different types of coelomocytes in echinoderms: phagocytes, vibratile cells, colorless and red spherule cells. However, Asteroidea and Ophiuroidea lack red spherule cells, and Crinoidea lack vibratile cells (reviewed by Ramirez-Gomez and Garcia-Arraras, 2010). Phagocytes constitute the most abundant coelomocyte type in the coelomic fluid (reviewed by Smith et al., 2010). Based on morphology, phagocytes can be categorized into three subtype populations. One subset consists of large discoidal phagocytes that have radially oriented actin bundles distributed throughout the cortex from the perinuclear region to the periphery (Henson et al., 2003; Henson et al., 1999). Another subset consists of large polygonal phagocytes that have actin bundles that are oriented across the cell creating a polygon cell shape (Henson et al., 1999). The third subset are smaller cells called small phagocytes (Gross et al., 2000) that are always present in filopodial form (Brockton et al., 2008). It is known that the sea urchins, Strongylocentrotus droebachiensis and S. purpuratus, are able to clear injected bacteria quickly from their coelomic fluid (Plytycz and Seljelid, 1993; Yui and Bayne, 1983). In addition, the different types of coelomocytes differ in their activity against microbial intruders. Phagocytic amoebocytes (herein referred to as phagocytes) and red spherule cells from Paracentrotus lividus exert a higher antibacterial activity against Gram-negative marine bacteria than the other populations of coelomocytes (Gerardi et al., 1990). When erythrocytes are opsonized by molecules in the coelomic fluid, this enhances the capacity of phagocytes from S. nudus to take up the erythrocytes (Ito et al., 1992). Several humoral factors are involved in defense processes such as clotting, opsonization, encapsulation, cell lysis, and wound healing (Gross et al., 1999). For example, the coelomic fluid from four sea urchin 
species, Anthocidaris crassispina, Pseudocentrotus depressus, Hemicentrotus pulcherrimus, and Holothuria polii, has hemagglutinating activity against mammalian erythrocytes (Canicattì and Parrinello, 1985; Ryoyama, 1974). An agglutinin from the coelomic fluid of the sea urchin $P$. lividus not only agglutinates animal erythrocytes but also promotes adhesion of the autologous coelomocytes (Canicatti et al., 1992). Echinoderm lectins, which are carbohydrate binding proteins, function to bind erythrocytes (Matsui et al., 1994), agglutinate bacteria (Kamiya et al., 1992), and assist in cell adhesion (Ozeki et al., 1991). In addition to AMPs, the innate immune system of echinoderms also has a number of antimicrobial components such as lysozyme, which play an important role in the echinoderm defense system. Generally, lysozymes show antimicrobial functions against Gram-positive bacteria and have been detected in asteroids (Bachali et al., 2004; Jollès and Jollès, 1975), echinoids (Shimizu et al., 1999), and holothuroids (Cong et al., 2009). A larval lysate of P. lividus has lysozyme-like and antibacterial activity against marine bacteria (Stabili et al., 1994). It is possible that lysozyme, AMPs and other antimicrobial factors act synergistically to provide an effective defense against microbial infections.

The first echinoderm genome to be completely sequenced was the genome of $S$. purpuratus (Sodergren et al., 2006). The sequence revealed a complex immune gene repertoire, indicating that sea urchins have an astonishingly high diversity of immune molecules (Hibino et al., 2006; Rast et al., 2006). Analysis of the S. purpuratus genome has uncovered an extreme expansion of several immune recognition receptor families. The genome sequence revealed 253 Toll-like receptor (TLR) genes (Buckley and Rast, 2012), more than 200 NACHT domain-LRR (NLR) genes and 218 scavenger receptor genes (Rast et al., 2006). Another large putative immune response gene family encodes the Sp185/333 protein family, which was initially identified by analyzing transcripts from LPS challenged sea urchins (Nair et al., 2005; Terwilliger et al., 2006). Of 171 genes from the Sp185/333 family that were sequenced, there were 121 unique 
gene sequences, and 689 cDNA sequences (Terwilliger et al., 2006; 2007) resulted in a total of 51 different element patterns (Buckley and Smith, 2007); reviewed by Smith (2012). Furthermore, the $S$. purpuratus genome contains homologues of the vertebrate complement protein $\mathrm{C} 3$ and factor B, called SpC3 and SpBf, respectively (reviewed by Smith et al., 2001). They were the first complement components to be identified in an invertebrate. The expression of the gene Sp064 that encodes SpC3 is upregulated after LPS challenge (Clow et al., 2000) and shows typical C3 function by binding to both methylamine and yeast and functioning as an opsonin (Clow et al., 2004). In addition, two transcripts from S. purpuratus encode putative complement proteins with domains that are also present in C6 and C7 (Multerer and Smith, 2004). Their deduced proteins might participate in the terminal complement pathway or act as complement regulatory proteins in sea urchins.

Although the recent acquisition of genetic information of echinoderms, such as the $S$. purpuratus genome sequence, allows us a glance at the complexity of the echinoderm immune system, we are far from understanding the immune system of the echinoderms. This is specially true for immune effectors such as antimicrobial compounds, which are understudied and very poorly understood. Considering the intriguing number and diversity of species in the Echinoderm phylum, their microbe-rich habitat, and mostly untapped genetic information, it is not surprising that echinoderms are targeted as a source for discovering novel antimicrobial peptides.

\section{AMPs}

While the amino acid composition which defines the structure of AMPs is diverse, some basic features seem to be common. AMPs are relatively short amino acid sequences, usually less than 100 amino acids (Ganz, 2003; Maroti et al., 2011), and according to the APD database, the average length of all registered peptides is around 32 residues with an average net positive charge of 3.18 (Wang et al., 2009). AMPs commonly contain many positively charged residues 
such as arginine and lysine, which result in the net positive charge (Hancock and Sahl, 2006; Zasloff, 2002). Most antimicrobial peptides fold into amphipathic structures, which reflect the relative abundance and polarization of hydrophobic and hydrophilic domains in their structural conformation. These fundamental features of AMPs also determine their antimicrobial properties such that the hydrophobic regions enable water-soluble AMPs to interact with the hydrophobic lipid bilayer of bacterial cell membranes (Brogden, 2005; Matsuzaki, 1999), which are known to be predominantly composed of phosphatidylglycerol, cardiolipin, or phosphatidylserine, resulting in a negative net charge on their outer leaflet (Yeaman and Yount, 2003). Studies on both artificial model membranes and bacterial membranes have shown that AMP-membrane interaction is initiated by electrostatic attraction (Scott et al., 1999; Silvestro et al., 1997; Zhao et al., 2001), followed by attachment (Heller et al., 1999; Huang, 2000; Wu et al., 1995), insertion (Lee et al., 2004; Yang et al., 2001), which leads to the loss of membrane integrity (Lee et al., 2004) and ion leakage through transmembrane pores or detergent-like solubilization of the cell membrane. Several models have been proposed to describe the mechanisms of action involved in AMP-dependent membrane damage that occurs when the AMP concentration reaches a certain threshold of a peptide/membrane lipid ratio. The AMPs form peptide helices that insert into the membrane either as a toroidal pore, a barrel stave, or a carpet model. The 'toroidal pore' model suggests that the lipid layer bends continuously and associates with the hydrophobic region of peptide forming the pore (Matsuzaki et al., 1996; Matsuzaki et al., 1998). According to the 'barrel-stave model', peptide helices insert into the membrane as parallel staves and form barrel-like pores (Cantor, 2002; He et al., 1995; Lee et al., 2004; Yang et al., 2001). In the 'carpet model', peptides show 'detergent-like' activity and disrupt the bilayer by forming micelles (Bolintineanu and Kaznessis, 2011; Ladokhin and White, 2001; Shai, 1999). In addition, the pores formed by AMPs in supported lipid bilayers can expand in size from the nano to micrometer scale resulting in a point of complete membrane 
disintegration (Rakowska et al., 2013). Some AMPs are able to translocate across the membrane and interact with intracellular targets. The mammalian proline-rich AMPs PR-39 and indolicidin inhibit protein and/or DNA synthesis in Escherichia coli (Boman et al., 1993; Subbalakshmi and Sitaram, 1998). In addition, buforin II and tachyplesin can bind nucleic acids (Park et al., 1998; Yonezawa et al., 1992); histatins reduce enzyme activity (Kavanagh and Dowd, 2004); and mersacidin inhibits cell wall synthesis (Brotz et al., 1998). Furthermore, AMPs are typically active against microbes in a dose-dependent manner, whether they act on the membrane or intracellular targets (Jang et al., 2010; Mochon and Liu, 2008; Muñoz et al., 2012; Romani et al., 2013; Vasudevan et al., 2008).

As a group of crucial immune-related molecules in multicellular organisms, it is not surprising that some AMPs have multiple roles, which not only have a direct antimicrobial function but also act indirectly as modulators of innate immunity, such as inducing chemokine production and influencing the processes of apoptosis, angiogenesis, and wound healing (Guilhelmelli et al., 2013; Hancock and Sahl, 2006). For example, magainin and gomesin induce apoptosis by increasing the activity of caspase-3, which is a frequently activated death protease (Cruz-Chamorro et al., 2006; Paredes-Gamero et al., 2012). PR-39 is involved in the regulation of angiogenesis (Li et al., 2000), promotion of wound repair (Gallo et al., 1994; Shi et al., 1996), and modulation of cytokine production (Veldhuizen et al., 2014). Therefore, such moonlighting functions should always be considered when AMPs are discovered or used as drug leads.

AMPs play an important role in host defense and might therefore serve as models for pharmaceutical drug leads. The pharmaceutical industry has shown a growing interest in AMPs, due to their attractive properties, such as high target specificity, high potency, and minimal toxicity/side-effects to the patient (Góngora-Benítez et al., 2014; Northfield et al., 2014). Examples of AMPs that have entered clinical trials are the lactoferricin derivative LTX-109 
and the indolicidin variant CP-226 called omiganan (Hancock and Sahl, 2006). Historically, AMPs have mainly been isolated from mammals, insects and plants. In recent years, however, the focus of bioprospecting activities has been shifting towards marine resources. Echinoderms, which have approximately 7,000 extant species and contribute significantly to marine biodiversity, are therefore expected to be a valuable source of bioactive and therapeutic peptides. What we currently know about some of the AMPs in echinoderms and their activities is the focus of the remainder of this review.

\section{AMPs in Echinoderms}

The first completely sequenced genes encoding AMPs in echinoderms were the strongylocins, which are expressed in the coelomocytes of the green sea urchin, $S$. droebachiensis (Li et al., 2008). This family of peptides includes two native members, named SdStrongylocins 1 and 2, and each has putative isoforms (SdStrongylocins $1 b$ and $2 b$ ). Native SdStrongylocin 1 is a peptide of 48 amino acids of $5.6 \mathrm{kDa}$ with an isoelectric point $(p I)$ of 9.34, while native SdStrongylocin 2 has 51 amino acids, is $5.8 \mathrm{kDa}$ with a $p I$ of 9.65. The SdStrongylocins display potent activity against both Gram-positive and Gram-negative bacteria at minimal inhibitory concentrations (MIC) of $1.3-2.5 \mu \mathrm{M}$. Listonella anguillarum, a marine fish pathogen, is especially susceptible to SdStrongylocin 2 . The peptides are cysteine rich, with six cysteines distributed throughout the sequence (Fig. 1A). Cysteine-rich AMPs have been discovered in many species from both the animal and plant kingdoms. The number of cysteines and their location pattern in the sequence determines the formation of disulfide bridges and the conformational structure of the peptides, which influences the antimicrobial activity of the AMPs (Selsted and Ouellette, 2005). The human native neutrophil $\alpha$-defensin, which has six cysteines, is active against viral or bacterial targets but loses this activity when linearized (Daher et al., 1986; Mandal and Nagaraj, 2002). A cysteine-rich AMP from a legume that is correctly folded with regard to the disulfide bonds is 
not only dramatically more active against bacteria but also more stable than peptides that are alternatively folded with incorrect disulfide bonds (Haag et al., 2012). Strongylocins have a unique cysteine arrangement pattern compared to cysteine location pattern of other cysteine rich AMPs (Table 1). The cysteines form three disulfide bonds, which may influence the antimicrobial activity of the peptide and protect the molecule from proteolytic degradation during biosynthesis in the coelomocyte and subsequent function upon secretion in the presence of microbes (Li et al., 2008; Selsted and Ouellette, 2005). Although the disulfide bonds in the stronglocins are important for the peptide activity, the exact orientation of the disulfide bonds that function in the native peptides is, however, currently unknown.

Homologous peptides of SdStrongylocin are also expressed in the purple sea urchin, $S$. purpuratus, and named SpStrongylocins 1 and 2 (Li et al., 2010a). Recombinant SpStrongylocins ( $r$ SpStrongylocins) are active against both Gram-positive and Gram-negative bacteria; however, membrane integrity studies showed that $r$ SpStrongylocins 1 and 2 do not enhance the permeability of the bacterial membrane (Li et al., 2010a). This suggests that SpStrongylocins may have intracellular targets or affect microbial killing in other ways. Based on the identical cysteine location pattern and high sequence similarity among the SdStrongylocins and SpStrongylocins, especially between SdStrongylocin 1 and SpStrongylocin 1, it is likely that the strongylocins employ a similar mode of antimicrobial action.

Another set of AMPs identified from the coelomocytes of $S$. droebachiensis are centrocins 1 and 2 (Li et al., 2010b). The native forms of two similar peptides isolated from $S$. droebachiensis were named Centrocin $1(4.5 \mathrm{kDa})$ and Centrocin $2(4.4 \mathrm{kDa})$, respectively. Subsequent cDNA analyses revealed an isoform, which is closely related to Centrocin 1, therefore named Centrocin $1 \mathrm{~b}$. Centrocins 1 and 2 are cationic peptides with $p I$ s of 10.06 and 9.69, respectively, and are active against both Gram-positive and Gram-negative bacteria at a 
MIC range of $1.3-2.5 \mu \mathrm{M}$. The centrocins are heterodimeric peptides which consist of a heavy chain (30 aa) and a light chain (12 aa) that are linked by an internal disulfide bond (Fig. 1B and 1C). The heavy chain of the centrocins contributes to the antimicrobial activity of the heterodimer, while the light chain does not have any detectible activity or influence the activity of the heavy chain against microbes (Li et al., 2010b). Although the light chain of centrocins alone is inactive against microbes, the formation of a heterodimeric structure in the native centrocins infers that the light chain may aid in stabilization of the molecules and make the peptides more resistant to attack by proteases (Li et al., 2010b). Other dimeric AMPs that have been identified from other animals include distinctin from tree frog, Phyllomedusa distincta (Batista et al., 2001), cryptdin-related sequence (CRS) peptides from mouse, Mus musculus (Hornef et al., 2004), cathelicidin CAP11 from neutrophils of guinea pig, Cavia porcellus (Yomogida et al., 1996), PMAP36 from pig, Sus scrofa (Scocchi et al., 2005), dicynthaurin and halocidin from the tunicate, Halocynthia aurantium (Jang et al., 2002; Lee et al., 2001). The dimeric structure of these types of AMPs influences antimicrobial activity, solubility, and protease resistance (Dempsey et al., 2003; Dewan et al., 2009; Hara et al., 2001; Lee et al., 2008; Liu et al., 2010; Shin et al., 2010).

Analysis of the deduced sequences of strongylocins and centrocins (Fig. 1) shows that the putative precursor molecules have preprosequences and that the centrocins have an interchain region between the heavy chain and the light chain (Li et al., 2010a; Li et al., 2010b; Li et al., 2008). AMPs are often derived from larger precursor molecules (Zasloff, 2002), and hence, the AMPs become biologically active mature molecules after one or more post-translational modification steps that include the removal of a presequence (also called a signal sequence) and/or prosequences, hydroxylation, halogenation (usually bromination), and glycosylation (Wang, 2012). Presequences, functioning as signal sequences, are likely important for targeting the ribosome to the rough endoplasmic reticulum (ER) and for guiding protein 
translocation across the ER membrane (Coleman et al., 1985; Reddy et al., 2004). The presequences are highly conserved in SdStrongylocin 1, SpStrongylocins 1 and 2, but have a different sequence in SdStrongylocin 2; however, all are hydrophobic (Fig. 1). In addition, the centrocins (including the putative form from S. purpuratus) share a conserved presequence (Li et al., 2010b), which differs from the strongylocin presequences. Three sorts of presequences in sea urchin AMPs are conserved within each family, but divergent among them. This indicates that these presequences might have different evolutionary origins and exert various pathways for intracellular translocation. Prosequences of strongylocins and centrocins contain several negatively charged amino acids, which make these AMP precursors less cationic. Many prosequences are known to inhibit the activity of the precursor until they are cleaved (Neurath, 1989); however, prosequences may also act as intramolecular chaperones, which aid in proper folding of the mature AMP. Prosequences with a net negative charge, such as in strongylocin and centrocin prosequences, likely silence the activity of the AMPs in the precursor form and prior to activation in the coelomocyte. Therefore, it is not surprising that preprosequences are crucial for translocation and inactivation of precursor molecules until AMPs acquire mature functions by post-translational modifications.

Brominated natural products are broadly distributed in marine organisms, but few are peptides. The aromatic amino acid tryptophan contains a heterocyclic indole group with 5 possible carbon positions (carbon number 2, 4, 5, 6, and 7) where a hydrogen can be substituted with a bromine atom. Most natural brominated peptides isolated contain either 2-, 5-, or 6-bromothryptophan residues (Bittner et al., 2007). Protein containing brominated tryptophan is resistant to degradation by proteases (Shinnar et al., 2003). One example is styelin D, a 32-residue long AMP isolated from the tunicate Styela clavata, which contains a 6-bromotryptophan residue in its sequence. The native peptide exerts antibacterial activity 
against Staphylococcus aureus and methicillin-resistant S. aureus (MRSA) at a range of pH and salinity. However, a synthesized version of styelin D with a non-brominated tryptophan shows decreased activity at low $\mathrm{pH}$ and/or high salinity (Taylor et al., 2000). This suggests that the post-translational modification of styelin D may preserve the antimicrobial activity at low $\mathrm{pH}$ and/or high salinity. Similarly, the bromotryptophan-containing cathelicidins, isolated from the Atlantic hagfish (Myxine glutinosa), are likely to be less susceptible to proteolysis (Uzzell et al., 2003). Hedistin is another brominated AMP, isolated from the coelomocytes of the marine annelid Nereis diversicolor (Tasiemski et al., 2007), and here the non-halogenated synthetic peptide is equally active as the native peptide. This suggests that bromination is the basis for making the peptide more resistant to proteases rather than being required for the antimicrobial activity. Protease resistance would extend the activity in vivo and thereby sustain the antimicrobial activity. SdStrongylocin 2 also contains a bromotryptophan residue and shows potent activity against bacteria (Li et al., 2008); however, the recombinant SpStrongylocin 2 also shows antibacterial activity, even though the tryptophan residue is not brominated (Li et al., 2010a). Likewise, the centrocins have a bromotryptophan residue in their heavy chain, which, if not brominated, does not alter the microbicidal activity of these peptides (Bjorn et al., 2012). Although we cannot exclude the possibility that the bromination of the native dimeric centrocins and SdStrongylocin 2 may have some influence on their antimicrobial activity, this post-translational modification may have effects similar to that suggested for hedistin and the hagfish cathelicidins, which is to protect the peptides from protease degradation.

Sea urchins have four major populations of coelomocytes based on morphological differences (reviewed in Smith et al., 2010). Phagocytes constitute the majority of coelomocytes and are divided into three subtypes; however, cell separation techniques limit purification of the subtypes. Recent results of AMP gene expression from S. droebachiensis 
show that transcripts of SdStrongylocin 1 are present in the phagocyte class of coelomocytes and in a fraction that is composed of a mixture of vibratile and colorless spherule cells. Furthermore, transcripts of SdStrongylocin 2 are present in both phagocytes and red spherule cells, while transcripts of centrocin 1 are only present in phagocytes in cytoplasmic vesicles (Li et al., 2014). Phagocytes challenged with co-cultured bacteria in vitro, resulted in centrocin 1 attaching to these phagocytosed bacteria inside the phagolysosomes. These studies suggest that sea urchin AMPs exert their antibacterial activities inside of coelomocytes and not in the coelomic fluid. Therefore, presequences direct the precursors of centrocin to the lysosomes. This is in agreement with previous observations where antibacterial activity was detected in extracts of coelomocytes and not in extracts of cell-free coelomic fluid (Haug et al., 2002).

Sea urchin eggs are embedded in a jelly coat composed of polysaccharides and glycoproteins (Jondeung and Czihak, 1982), which, in combination with maternal molecules, provides immune protection to the embryos (Kitazume et al., 1994). During development, sea urchin embryos and larvae face pathogenic challenges in the marine environment once they emerge from the fertilization envelope as multi-cellular organisms with an ectodermal body wall that quickly develop the digestive tract. Transcripts of the gene $S p 064$, which encodes a homologue of complement $\mathrm{C} 3$ that functions as an opsonin (Clow et al., 2004), is present in unfertilized eggs and throughout embryogenesis (Shah et al., 2003). Phagocytosis of injected yeast cells has been observed for the secondary mesenchyme cells at the mid gastrula stage of Lytechinus variegatus (Silva, 2000), and pinocytosis occurs in the cells lining the stomach and intestine of the pluteus larvae of L. pictus (Huvard and Holland, 1986). The question is: when do AMPs contribute to sea urchin larval innate immunity? In S. droebachiensis, transcripts of SdStrongylocins are present in the early pluteus stage whereas transcripts of centrocin 1 are detected in the mid pluteus stage (Li et al., 2014). Moreover, centrocin 1 is 
mainly present in blastocoelar cells at coelomic vesicles and sacs around the stomach and esophagus, and also in a few blastocoelar cells that patrol close to the ectodermal walls in some arms. Thus, AMPs have a crucial role in immunity, not only in adult sea urchins but also in larvae.

There are several other AMPs that have been identified in echinoderms (Table 2). A number of partial peptide sequences that show antimicrobial activity were identified from a coelomocyte extract from the sea star Asterias rubens, including fragments of histone $\mathrm{H} 2 \mathrm{~A}$, actin and filamin A (Maltseva et al., 2007). These peptides, which have a molecular mass of $1.8-2.4 \mathrm{kDa}$, are highly cationic with a predicted $p I$ ranging from 11.3 to 12.3 . Four other AMPs were also detected in A. rubens coelomocytes, but the sequences were not identified. A coelomic fluid extract of the sea cucumber Cucumaria frondosa was purified by molecular sieve chromatography, and an unsequenced AMP of about $6 \mathrm{kDa}$ was detected (Beauregard et al., 2001). Two peptide fragments, called holothuroidins 1 and 2, from the sea cucumber $H$. tubulosa have activity against human pathogens, with MICs in the mM range (Schillaci et al., 2013). Helical wheel analysis indicated that the holothuroidins probably adapt to an $\alpha$-helical structure with considerable amphipathic character. Synthetic holothuroidins also inhibit biofilm formation of three bacterial strains, S aureus, S. epidermidis, and Pseudomonas aeruginosa. Another synthetic peptide, corresponding to the $\alpha$-helical region of CEL-III (a fragment of a lectin isolated from the sea cucumber C. echinata) shows strong antibacterial activity against $S$. aureus and Bacillus subtilis through a marked permeabilization of the bacterial cell membrane (Hatakeyama et al., 2004; Hisamatsu et al., 2008). Recently, peptides of $<5 \mathrm{kDa}$, which might be fragments of beta-thymosin, were detected in coelomocyte extracts of the sea urchin P. lividus, and show activity against Gram-positive and Gramnegative bacteria and inhibited the formation of biofilms (Schillaci et al., 2010; Schillaci et $a l ., 2012)$. Although these preliminary investigations only cover very few echinoderm 
species, the exciting findings infer that echinoderms deserve more efforts to discover new active compounds.

\section{Summary}

In the last few decades, thousands of AMPs have been characterized, and some of their killing mechanisms and other functions have been addressed. In order to identify potent antimicrobial agents, exploration has shifted from terrestrial species towards marine species that inhabit regions from the intertidal zone to the deep sea. Echinoderms, being the second largest group of deuterostomes, constitute a huge potential source for new bioactive peptides that may lead to new drugs. In this review, we have provided an overview of antimicrobial peptides found in echinoderms. A broad range of bioactivities have been attributed to AMPs, including bactericidal, fungicidal, anti-inflammatory activity, wound healing, and inhibition of biofilm formation. In addition, AMPs from echinoderms have provided insights into the functional importance of some post-translational modifications, and unique functional domains and conformational structures, which may benefit the design of new peptide drugs, such as proteolytic resistant AMPs, AMP mimetics, chimeric AMPs, AMP congeners, AMP conjugates, and immobilized AMPs (Brogden and Brogden, 2011).

AMPs are crucial effector molecules that are essential for effective echinoderm innate immunity. Li et al. (2014) demonstrated that AMPs appear and function from the early developmental stages throughout the remainder of the sea urchin lifespan. Although AMPs act as downstream effector molecules in animal immunity, mammalian AMPs are also considered as immunoregulatory molecules (Hancock and Sahl, 2006; Hilchie et al., 2013). However, there is currently no evidence to suggest that echinoderm AMPs function to modulate the expression of chemokines/cytokines during echinoderm immune defense. The complexity of immune receptors in echinoderms has been unveiled by the analysis of the genome of $S$. purpuratus (Rast et al., 2006). This complexity raises many questions such as how immune 
receptors can recognize and distinguish various pathogens, trigger signaling pathways, and activate effector molecules such as AMPs. Future work will help us to address questions of AMP activities and to better understand the role of AMPs in echinoderm immunity.

\section{Acknowledgements}

This work was supported by grants of the UiT The Arctic University of Norway, Tromsø Forskningsstiftelse and the Norwegian Research Council (208546/O30). 
Table 1. Cysteine location patterns in AMPs containing 6 cysteine residues.

\begin{tabular}{lll}
\hline Peptide family & Cysteine location patterns ${ }^{\text {a }}$ & Animals \\
\hline Buthinin, Cycloviolacins, Circulins & $\mathrm{C}-\mathrm{C}-\mathrm{C}-\mathrm{C}-\mathrm{C}-\mathrm{C}$ & Insects, plants \\
Thionins, Phoratoxin, & $\mathbf{C C}-\mathrm{C}-\mathrm{C}-\mathrm{C}-\mathrm{C}$ & Plants \\
Knottin-type AMPs, PaAMPs & $\mathrm{C}-\mathrm{C}-\mathbf{C C}-\mathrm{C}-\mathrm{C}$ & Plants \\
Tachystatins & $\mathrm{C}-\mathrm{C}-\overline{\mathbf{C C}}-\mathrm{C}-\mathrm{C}$ & Horseshoe crab \\
Strongylocins & $\mathrm{C}-\mathrm{C}-\mathrm{C}-\mathbf{C C}-\mathrm{C}$ & Echinoderms \\
Alpha-defensins & $\mathrm{C}-\mathrm{C}-\mathrm{C}-\mathrm{C}-\mathbf{C C}$ & Mammals \\
Beta-defensins & $\mathrm{C}-\mathrm{C}-\mathrm{C}-\mathrm{C}-\overline{\mathbf{C C}}$ & Mammals, birds \\
\hline
\end{tabular}

${ }^{a}$ Adjacent double cysteine residues are boxed. Information regarding cysteine arrangements in the different peptides was obtained from the Antimicrobial Peptide Database (Wang et al., 2009).

"-" one or more non-cysteine amino acids. 
Table 2. Antimicrobial peptides and proteins characterized in echinoderms.

\begin{tabular}{|c|c|c|c|c|}
\hline Class and genus & Origin & Peptides & MW (kDa) & Reference \\
\hline \multicolumn{5}{|l|}{ Asteroidea } \\
\hline Asterias rubens & Coelomocytes & $\begin{array}{l}\text { Fragments of Actin, } \\
\text { Histone } \mathrm{H} 2 \mathrm{~A} \text {, and } \\
\text { filamin } \mathrm{A}^{\mathrm{a}}\end{array}$ & $1.8-2.4$ & Maltseva et al., 2007 \\
\hline & Coelomocytes & Peptides & $2.6-4.7$ & Maltseva et al., 2007 \\
\hline \multicolumn{5}{|l|}{ Echinoidea } \\
\hline $\begin{array}{l}\text { Paracentrotus } \\
\text { lividus }\end{array}$ & Coelomocytes & $\begin{array}{l}\text { Fragments of } \beta- \\
\text { thymosin }^{\text {a }}\end{array}$ & $1.3-2.3$ & Schillaci et al., 2010 \\
\hline \multirow{2}{*}{$\begin{array}{l}\text { Strongylocentrotus } \\
\text { droebachiensis }\end{array}$} & Coelomocytes & SdStrongylocins & $5.6-5.8$ & Li et al., 2008 \\
\hline & Coelomocytes & Centrocins & $4.4-4.5$ & Li et al., 2010b \\
\hline S. purpuratus & $\begin{array}{l}\text { Coelomocyte } \\
\text { cDNA }\end{array}$ & SpStrongylocins ${ }^{b}$ & $5.6-6.1$ & Li et al., 2010a \\
\hline \multicolumn{5}{|l|}{ Holothuroidea } \\
\hline $\begin{array}{l}\text { Cucumaria } \\
\text { echinata }\end{array}$ & Whole body & $\begin{array}{l}\text { Fragments of CEL- } \\
\text { III protein }{ }^{\text {a, c }}\end{array}$ & $2.0-4.2$ & $\begin{array}{l}\text { Hatakeyama et al., } \\
2004\end{array}$ \\
\hline C. frondosa & Coelomic fluid & Sequence unknown & $\sim 6$ & Beauregard et al., 2001 \\
\hline $\begin{array}{l}\text { Holothuria } \\
\text { tubulosa }\end{array}$ & Coelomocytes & Holothuroidins ${ }^{\text {a, c }}$ & $1.4-1.5$ & Schillaci et al., 2013 \\
\hline
\end{tabular}

a Putative AMPs, derived from larger precursor molecules.

${ }^{\mathrm{b}}$ Recombinantly produced peptides.

c Synthetic peptides. 
A.
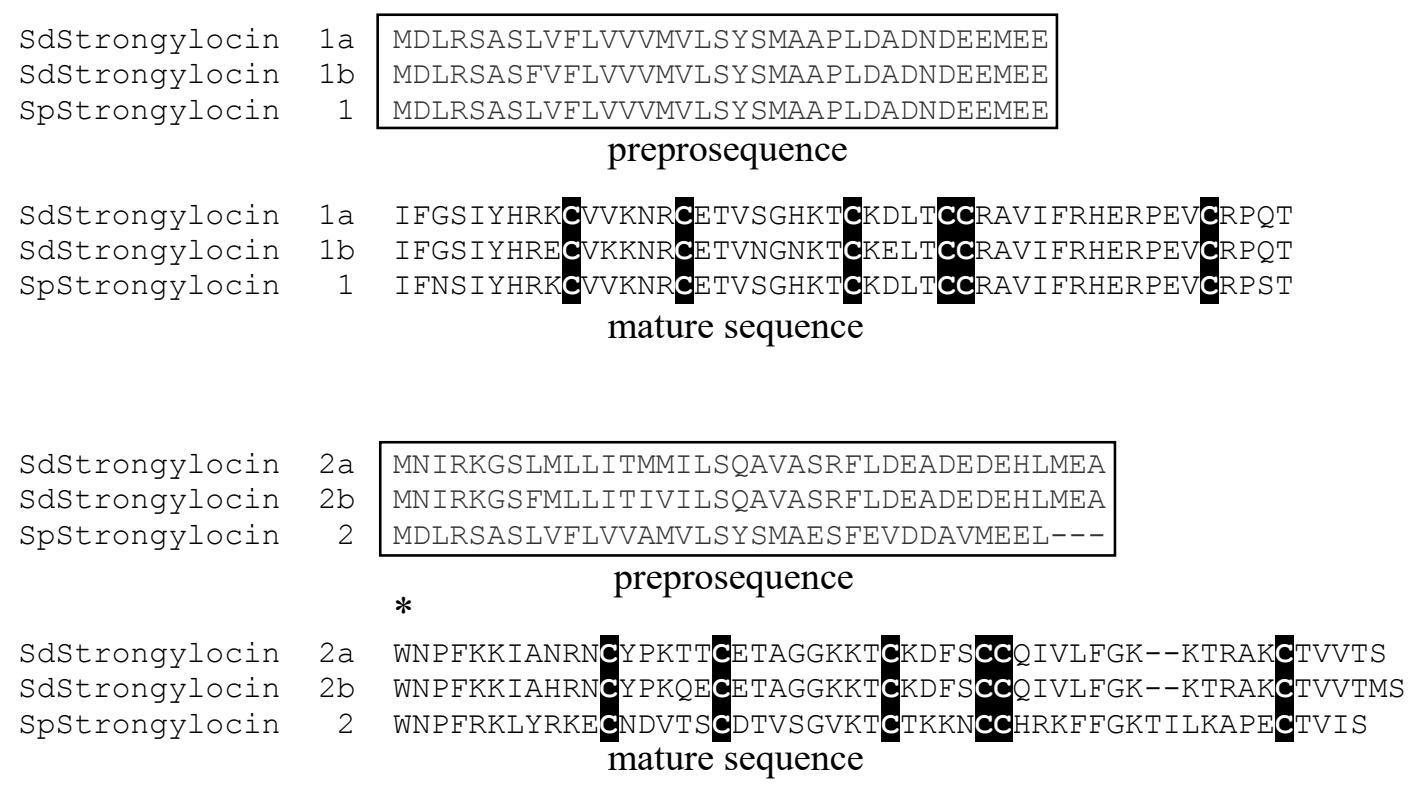

B.

Centrocin $1 \mathrm{a}$
Centrocin $1 \mathrm{~b}$
Centrocin 2

Centrocin $1 \mathrm{a}$ Centrocin 1b

Centrocin 2

C.

Centrocin $1 \mathrm{a}$

Centrocin 2
MMIKVALVLCA IVATSMVCAKDFEEQDALDALLNMMLPEEVAS PDDAVALQ
MMIKVALVLCAIVATSMVCAKNFEEQDALDTLLNMMLSEEVAS PDDAVALQ
MMIKVALVLCAIVATSMVCAKNFEEQDALDTLLNLMLSEEAASP-DAVALQ

MMIKVALVLCAIVATSMVCAKNFEEQDALD
preprosequence

$*$

GWFKKTFHKVSHAVKSGIHAGQRGCSALGF SPEEARVKI LTAI PEMREEDLSEEDLRGACAAAHAIGR
GWFKKTFHKVSHAVKSDIHAGQRGCSALGF SPEEARVKILTAFPEMKEEDLTEE GVRAVCAGAHAIGR
SWFSRTVHNVGNAVRKGIHAGQGVCSGLGLSPEEARVKI LSAVPEMREEDLSEEDLRAICAGAHAIGR heavy chain prosequence (interchain) light chain

$*$

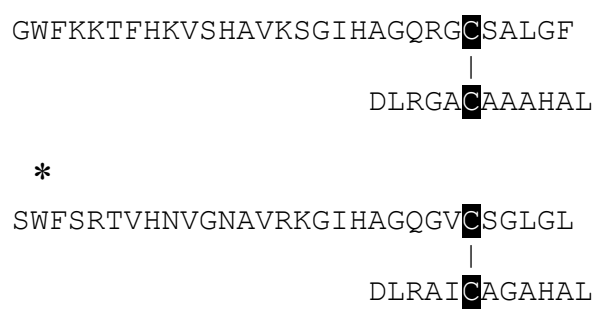

Figure 1. Alignment of SdStrongylocins from S. droebachiensis and SpStrongylocins from S. purpuratus (A), centrocins from $S$. droebachiensis (B), and the structure of centrocins (C). The preprosequences (or prosequence) are boxed. The first amino acid in the mature SdStrongylocin 2, SpStrongylocin 2 and the second amino acid in the mature centrocins are brominated tryptophans $(*)$. Cysteines are shaded in black. The gray shaded and boxed Cterminal dipeptides in the precursors of centrocins, are cleaved off in the mature peptides. 


\section{References}

Bachali, S., Bailly, X., Jolles, J., Jolles, P., Deutsch, J.S., 2004. The lysozyme of the starfish Asterias rubens. A paradygmatic type i lysozyme. Eur J Biochem 271, 237-242.

Batista, C.V., Scaloni, A., Rigden, D.J., Silva, L.R., Rodrigues Romero, A., Dukor, R., Sebben, A., Talamo, F., Bloch, C., 2001. A novel heterodimeric antimicrobial peptide from the treefrog Phyllomedusa distincta. FEBS Lett 494, 85-89.

Beauregard, K.A., Truong, N.T., Zhang, H., Lin, W., Beck, G., 2001. The detection and isolation of a novel antimicrobial peptide from the echinoderm, Cucumaria frondosa. Adv Exp Med Biol 484, 55-62.

Bittner, S., Scherzer, R., Harlev, E., 2007 The five bromotryptophans. Amino Acids 33, 19-42. Bjorn, C., Hakansson, J., Myhrman, E., Sjostrand, V., Haug, T., Lindgren, K., Blencke, H.M., Stensvåg, K., Mahlapuu, M., 2012. Anti-infectious and anti-inflammatory effects of peptide fragments sequentially derived from the antimicrobial peptide centrocin 1 isolated from the green sea urchin, Strongylocentrotus droebachiensis. AMB Express 2, 67.

Bolintineanu, D.S., Kaznessis, Y.N., 2011. Computational studies of protegrin antimicrobial peptides: A review. Peptides 32, 188-201.

Boman, H.G., Agerberth, B., Boman, A., 1993. Mechanisms of action on Escherichia coli of cecropin P1 and PR-39, two antibacterial peptides from pig intestine. Infect Immun 61, 2978-2984.

Brockton, V., Henson, J.H., Raftos, D.A., Majeske, A.J., Kim, Y.O., Smith, L.C., 2008. Localization and diversity of $185 / 333$ proteins from the purple sea urchin--unexpected protein-size range and protein expression in a new coelomocyte type. J Cell Sci 121, 339348.

Brogden, K.A., 2005. Antimicrobial peptides: pore formers or metabolic inhibitors in bacteria? Nat Rev Microbiol 3, 238-250.

Brogden, N.K., Brogden, K.A., 2011. Will new generations of modified antimicrobial peptides improve their potential as pharmaceuticals? Int J Antimicrob Agents 38, 217-225.

Brotz, H., Bierbaum, G., Leopold, K., Reynolds, P.E., Sahl, H.G., 1998. The lantibiotic mersacidin inhibits peptidoglycan synthesis by targeting lipid II. Antimicrob Agents Chemother 42, 154-160.

Buckley, K.M., Rast, J.P., 2012. Dynamic evolution of toll-like receptor multigene families in echinoderms. Front Immunol 3, 136.

Buckley, K.M., Smith, L.C., 2007. Extraordinary diversity among members of the large gene family, 185/333, from the purple sea urchin, Strongylocentrotus purpuratus. BMC Mol Biol 8, 68 .

Canicatti, C., Pagliara, P., Stabili, L., 1992. Sea urchin coelomic fluid agglutinin mediates coelomocyte adhesion. Eur J Cell Biol 58, 291-295.

Canicattì, C., Parrinello, N., 1985. Hemagglutinin and hemolysin levels in the coelomic fluid from Holothuria polii (Echinodermata) following sheep erythrocyte injection. Biol Bull $168,175-182$.

Cantor, R.S., 2002. Size distribution of barrel-stave aggregates of membrane peptides: influence of the bilayer lateral pressure profile. Biophys J 82, 2520-2525.

Clow, L.A., Gross, P.S., Shih, C.S., Smith, L.C., 2000. Expression of SpC3, the sea urchin complement component, in response to lipopolysaccharide. Immunogenetics 51, 10211033.

Clow, L.A., Raftos, D.A., Gross, P.S., Smith, L.C., 2004. The sea urchin complement homologue, SpC3, functions as an opsonin. J Exp Biol 207, 2147-2155.

Coleman, J., Inukai, M., Inouye, M., 1985. Dual functions of the signal peptide in protein transfer across the membrane. Cell 43, 351-360. 
Cong, L., Yang, X., Wang, X., Tada, M., Lu, M., Liu, H., Zhu, B., 2009. Characterization of an i-type lysozyme gene from the sea cucumber Stichopus japonicus, and enzymatic and nonenzymatic antimicrobial activities of its recombinant protein. J Biosci Bioeng 107, 583 588.

Cruz-Chamorro, L., Puertollano, M.A., Puertollano, E., de Cienfuegos, G.Á., de Pablo, M.A., 2006. In vitro biological activities of magainin alone or in combination with nisin. Peptides 27, 1201-1209.

Daher, K.A., Selsted, M.E., Lehrer, R.I., 1986. Direct inactivation of viruses by human granulocyte defensins. J Virol 60, 1068-1074.

Dempsey, C.E., Ueno, S., Avison, M.B., 2003. Enhanced membrane permeabilization and antibacterial activity of a disulfide-dimerized magainin analogue. Biochemistry 42, $402-$ 409.

Dewan, P.C., Anantharaman, A., Chauhan, V.S., Sahal, D., 2009. Antimicrobial action of prototypic amphipathic cationic decapeptides and their branched dimers. Biochemistry 48, $5642-5657$.

Gallo, R.L., Ono, M., Povsic, T., Page, C., Eriksson, E., Klagsbrun, M., Bernfield, M., 1994. Syndecans, cell surface heparan sulfate proteoglycans, are induced by a proline-rich antimicrobial peptide from wounds. Proc Natl Acad Sci U S A 91, 11035-11039.

Ganz, T., 2003. Defensins: antimicrobial peptides of innate immunity. Nat Rev Immunol 3, 710-720.

Gerardi, P., Lassegues, M., Canicatti, C., 1990. Cellular distribution of sea urchin antibacterial activity. Biol Cell 70, 153-157.

Góngora-Benítez, M., Tulla-Puche, J., Albericio, F., 2014. Multifaceted roles of disulfide bonds. Peptides as therapeutics. Chem Rev 114, 901-926.

Gross, P.S., Al-Sharif, W.Z., Clow, L.A., Smith, L.C., 1999. Echinoderm immunity and the evolution of the complement system. . Dev Comp Immunol 23, 533-533.

Gross, P.S., Clow, L.A., Smith, L.C., 2000. SpC3, the complement homologue from the purple sea urchin, Strongylocentrotus purpuratus, is expressed in two subpopulations of the phagocytic coelomocytes. Immunogenetics 51, 1034-1044.

Guilhelmelli, F., Vilela, N., Albuquerque, P., Derengowski, L.D., Silva-Pereira, I., Kyaw, C.M., 2013. Antibiotic development challenges: the various mechanisms of action of antimicrobial peptides and of bacterial resistance. Frontiers in microbiology 4, 353-365.

Haag, A.F., Kerscher, B., Dall'Angelo, S., Sani, M., Longhi, R., Baloban, M., Wilson, H.M., Mergaert, P., Zanda, M., Ferguson, G.P., 2012. Role of cysteine residues and disulfide bonds in the activity of a legume root nodule-specific, cysteine-rich peptide. J Biol Chem 287, 10791-10798.

Hancock, R.E.W., Sahl, H.G., 2006. Antimicrobial and host-defense peptides as new antiinfective therapeutic strategies. Nat Biotechnol 24, 1551-1557.

Hara, T., Kodama, H., Kondo, M., Wakamatsu, K., Takeda, A., Tachi, T., Matsuzaki, K., 2001. Effects of peptide dimerization on pore formation: Antiparallel disulfide-dimerized magainin 2 analogue. Biopolymers 58, 437-446.

Hatakeyama, T., Suenaga, T., Eto, S., Niidome, T., Aoyagi, H., 2004. Antibacterial activity of peptides derived from the $\mathrm{C}$-terminal region of a hemolytic lectin, CEL-III, from the marine invertebrate Cucumaria echinata. J Biochem 135, 65-70.

Haug, T., Kjuul, A.K., Styrvold, O.B., Sandsdalen, E., Olsen, O.M., Stensvåg, K., 2002. Antibacterial activity in Strongylocentrotus droebachiensis (Echinoidea), Cucumaria frondosa (Holothuroidea), and Asterias rubens (Asteroidea). J Invertebr Pathol 81, 94-102.

He, K., Ludtke, S.J., Huang, H.W., Worcester, D.L., 1995. Antimicrobial peptide pores in membranes detected by neutron in-plane scattering. Biochemistry 34, 15614-15618. 
Heller, W.T., Waring, A.J., Lehrer, R.I., Harroun, T.A., Weiss, T.M., Yang, L., Huang, H.W., 1999. Membrane thinning effect of the $\beta$-sheet antimicrobial protegrin. Biochemistry 39 , 139-145.

Henson, J.H., Kolnik, S.E., Fried, C.A., Nazarian, R., McGreevy, J., Schulberg, K.L., Detweiler, M., Trabosh, V.A., 2003. Actin-based centripetal flow: Phosphatase inhibition by Calyculin-A alters flow pattern, actin organization, and actomyosin distribution. Cell Motil Cytoskel 56, 252-266.

Henson, J.H., Svitkina, T.M., Burns, A.R., Hughes, H.E., MacPartland, K.J., Nazarian, R., Borisy, G.G., 1999. Two components of actin-based retrograde flow in sea urchin coelomocytes. Mol Biol Cell 10, 4075-4090.

Hibino, T., Loza-Coll, M., Messier, C., Majeske, A.J., Cohen, A.H., Terwilliger, D.P., Buckley, K.M., Brockton, V., Nair, S.V., Berney, K., Fugmann, S.D., Anderson, M.K., Pancer, Z., Cameron, R.A., Smith, L.C., Rast, J.P., 2006. The immune gene repertoire encoded in the purple sea urchin genome. Dev Biol 300, 349-365.

Hilchie, A.L., Wuerth, K., Hancock, R.E., 2013. Immune modulation by multifaceted cationic host defense (antimicrobial) peptides. Nat Chem Biol 9, 761-768.

Hisamatsu, K., Tsuda, N., Goda, S., Hatakeyama, T., 2008. Characterization of the $\alpha$-helix region in domain 3 of the haemolytic lectin CEL-III: implications for self-oligomerization and haemolytic processes. J Biochem 143, 79-86.

Hornef, M.W., Putsep, K., Karlsson, J., Refai, E., Andersson, M., 2004. Increased diversity of intestinal antimicrobial peptides by covalent dimer formation. Nat Immunol 5, 836-843.

Huang, H.W., 2000. Action of antimicrobial peptides: two-state model. Biochemistry 39, 83478352.

Huvard, A.L., Holland, N.D., 1986. Pinocytosis of ferritin from the gut lumen in larvae of a sea star (Patiria miniata) and a sea urchin (Lytechinus pictus). Dev Growth Differ 28, 43-51.

Ito, T., Matsutani, T., Mori, K., Nomura, T., 1992. Phagocytosis and hydrogen peroxide production by phagocytes of the sea urchin Strongylocentrotus nudus. Dev Comp Immunol 16, 287-294.

Jang, W.S., Bajwa, J.S., Sun, J.N., Edgerton, M., 2010. Salivary histatin 5 internalization by translocation, but not endocytosis, is required for fungicidal activity in Candida albicans. Mol Microbiol 77, 354-370.

Jang, W.S., Kim, K.N., Lee, Y.S., Nam, M.H., Lee, I.H., 2002. Halocidin: a new antimicrobial peptide from hemocytes of the solitary tunicate, Halocynthia aurantium. FEBS Lett 521, 81-86.

Jollès, J., Jollès, P., 1975. The losozyme from Asterias rubens. Eur J Biochem 54, 19-23.

Jondeung, A., Czihak, G., 1982. Histochemical studies of jelly coat of sea-urchin eggs during oogenesis. Histochemistry 76, 123-136.

Kamiya, H., Muramoto, K., Goto, R., Sakai, M., 1992. Lectins in the hemolymph of a starfish, Asterina pectinifera: purification and characterization. Dev Comp Immunol 16, 243-250.

Kavanagh, K., Dowd, S., 2004. Histatins: antimicrobial peptides with therapeutic potential. J Pharm Pharmacol 56, 285-289.

Kitazume, S., Kitajima, K., Inoue, S., Troy, F.A., II, Cho, J.W., Lennarz, W.J., Inoue, Y., 1994. Identification of polysialic acid-containing glycoprotein in the jelly coat of sea urchin eggs. Occurrence of a novel type of polysialic acid structure. J Biol Chem 269, 22712-22718.

Kondo, M., Akasaka, K., 2012. Current status of echinoderm genome analysis - what do we know? Curr Genomics 13, 134-143.

Ladokhin, A.S., White, S.H., 2001. 'Detergent-like' permeabilization of anionic lipid vesicles by melittin. Biochim Biophys Acta 1514, 253-260.

Lee, I.H., Lee, Y.S., Kim, C.H., Kim, C.R., Hong, T., Menzel, L., Boo, L.M., Pohl, J., Sherman, M.A., Waring, A., Lehrer, R.I., 2001. Dicynthaurin: an antimicrobial peptide from 
hemocytes of the solitary tunicate, Halocynthia aurantium. Biochim Biophys Acta 1527, 141-148.

Lee, J.Y., Yang, S.T., Lee, S.K., Jung, H.H., Shin, S.Y., Hahm, K.S., Kim, J.I., 2008. Saltresistant homodimeric bactenecin, a cathelicidin-derived antimicrobial peptide. FEBS J 275, 3911-3920.

Lee, M.T., Chen, F.Y., Huang, H.W., 2004. Energetics of pore formation induced by membrane active peptides. Biochemistry 43, 3590-3599.

Li, C., Blencke, H.M., Haug, T., Jorgensen, O., Stensvåg, K., 2014. Expression of antimicrobial peptides in coelomocytes and embryos of the green sea urchin (Strongylocentrotus droebachiensis). Dev Comp Immunol 43, 106-113.

Li, C., Blencke, H.M., Smith, L.C., Karp, M.T., Stensvåg, K., 2010a. Two recombinant peptides, SpStrongylocins 1 and 2, from Strongylocentrotus purpuratus, show antimicrobial activity against Gram-positive and Gram-negative bacteria. Dev Comp Immunol 34, 286-292.

Li, C., Haug, T., Moe, M.K., Styrvold, O.B., Stensvåg, K., 2010b. Centrocins: isolation and characterization of novel dimeric antimicrobial peptides from the green sea urchin, Strongylocentrotus droebachiensis. Dev Comp Immunol 34, 959-968.

Li, C., Haug, T., Styrvold, O.B., Jorgensen, T.O., Stensvåg, K., 2008. Strongylocins, novel antimicrobial peptides from the green sea urchin, Strongylocentrotus droebachiensis. Dev Comp Immunol 32, 1430-1440.

Li, J., Post, M., Volk, R., Gao, Y., Li, M., Metais, C., Sato, K., Tsai, J., Aird, W., Rosenberg, R.D., Hampton, T.G., Sellke, F., Carmeliet, P., Simons, M., 2000. PR39, a peptide regulator of angiogenesis. Nat Medicine 6, 49-55.

Liu, S.P., Zhou, L., Lakshminarayanan, R., Beuerman, R.W., 2010. Multivalent antimicrobial peptides as therapeutics: design principles and structural diversities. Int J Peptide Res Therapeutics 16, 199-213.

Maltseva, A.L., Aleshina, G.M., Kokryakov, V.N., Krasnodembskii, E.G., 2007. Diversity of antimicrobial peptides in acidic extracts from coelomocytes of starfish Asterias rubens L. Vestnik Sankt-Peterburgskogo Universiteta 3, 85-94.

Mandal, M., Nagaraj, R., 2002. Antibacterial activities and conformations of synthetic alphadefensin HNP-1 and analogs with one, two and three disulfide bridges. J Pept Res 59, 95 104.

Maroti, G., Kereszt, A., Kondorosi, E., Mergaert, P., 2011. Natural roles of antimicrobial peptides in microbes, plants and animals. Res Microbiol 162, 363-374.

Matsui, T., Ozeki, Y., Suzuki, M., Hino, A., Titani, K., 1994. Purification and characterization of two Ca2+-dependent lectins from coelomic plasma of sea cucumber, Stichopus japonicus. J Biochem 116, 1127-1133.

Matsuzaki, K., 1999. Why and how are peptide-lipid interactions utilized for self-defense? Magainins and tachyplesins as archetypes. Biochimica et Biophysica Acta (BBA) Biomembranes 1462, 1-10.

Matsuzaki, K., Murase, O., Fujii, N., Miyajima, K., 1996. An antimicrobial peptide, magainin 2 , induced rapid flip-flop of phospholipids coupled with pore formation and peptide translocation. Biochemistry 35, 11361-11368.

Matsuzaki, K., Sugishita, K., Ishibe, N., Ueha, M., Nakata, S., Miyajima, K., Epand, R.M., 1998. Relationship of membrane curvature to the formation of pores by magainin 2 . Biochemistry 37, 11856-11863.

Mochon, A.B., Liu, H., 2008. The antimicrobial peptide histatin-5 causes a spatially restricted disruption on the Candida albicans surface, allowing rapid entry of the peptide into the cytoplasm. PLoS pathogens 4, e1000190. 
Multerer, K.A., Smith, L.C., 2004. Two cDNAs from the purple sea urchin, Strongylocentrotus purpuratus, encoding mosaic proteins with domains found in factor $\mathrm{H}$, factor $\mathrm{I}$, and complement components C6 and C7. Immunogenetics 56, 89-106.

Muñoz, A., Marcos, J.F., Read, N.D., 2012. Concentration-dependent mechanisms of cell penetration and killing by the de novo designed antifungal hexapeptide PAF26. Mol Microbiol 85, 89-106.

Nair, S.V., Del Valle, H., Gross, P.S., Terwilliger, D.P., Smith, L.C., 2005. Macroarray analysis of coelomocyte gene expression in response to LPS in the sea urchin. Identification of unexpected immune diversity in an invertebrate. Physiological Genomics 22, 33-47.

Neurath, H., 1989. Proteolytic processing and physiological regulation. Trends Biochem Sci $14,268-271$.

Northfield, S.E., Wang, C.K., Schroeder, C.I., Durek, T., Kan, M.W., Swedberg, J.E., Craik, D.J., 2014. Disulfide-rich macrocyclic peptides as templates in drug design. Eur J Med Chem 77, 248-257.

Ozeki, Y., Matsui, T., Titani, K., 1991. Cell adhesive activity of two animal lectins through different recognition mechanisms. FEBS Letters 289, 145-147.

Paredes-Gamero, E.J., Martins, M.N.C., Cappabianco, F.A.M., Ide, J.S., Miranda, A., 2012. Characterization of dual effects induced by antimicrobial peptides: Regulated cell death or membrane disruption. Biochimica et Biophysica Acta (BBA) - General Subjects 1820, 1062-1072.

Park, C.B., Kim, H.S., Kim, S.C., 1998. Mechanism of action of the antimicrobial peptide buforin II: buforin II kills microorganisms by penetrating the cell membrane and inhibiting cellular functions. Biochem Biophys Res Commun 244, 253-257.

Plytycz, B., Seljelid, R., 1993. Bacterial clearance by the sea urchin, Strongylocentrotus droebachiensis. Dev Comp Immunol 17, 283-289.

Rakowska, P.D., Jiang, H., Ray, S., Pyne, A., Lamarre, B., Carr, M., Judge, P.J., Ravi, J., Gerling, U.I., Koksch, B., Martyna, G.J., Hoogenboom, B.W., Watts, A., Crain, J., Grovenor, C.R., Ryadnov, M.G., 2013. Nanoscale imaging reveals laterally expanding antimicrobial pores in lipid bilayers. Proc Natl Acad Sci U S A 110, 8918-8923.

Rast, J.P., Smith, L.C., Loza-Coll, M., Hibino, T., Litman, G.W., 2006. Genomic insights into the immune system of the sea urchin. Science 314, 952-956.

Reddy, K.V., Yedery, R.D., Aranha, C., 2004. Antimicrobial peptides: premises and promises. Int J Antimicrob Agents 24, 536-547.

Romani, A.A., Baroni, M.C., Taddei, S., Ghidini, F., Sansoni, P., Cavirani, S., Cabassi, C.S., 2013. In vitro activity of novel in silico-developed antimicrobial peptides against a panel of bacterial pathogens. J Peptide Sci 19, 554-565.

Ryoyama, K., 1974. Studies on the biological properties of coelomic fluid of sea urchin. II. Naturally occurring hemagglutinin in sea urchin. Biol Bull 146, 404-414.

Schillaci, D., Arizza, V., Parrinello, N., Di Stefano, V., Fanara, S., Muccilli, V., Cunsolo, V., Haagensen, J.J.A., Molin, S., 2010. Antimicrobial and antistaphylococcal biofilm activity from the sea urchin Paracentrotus lividus. J Applied Microbiol 108, 17-24.

Schillaci, D., Cusimano, M.G., Cunsolo, V., Saletti, R., Russo, D., Vazzana, M., Vitale, M., Arizza, V., 2013. Immune mediators of sea-cucumber Holothuria tubulosa (Echinodermata) as source of novel antimicrobial and anti-staphylococcal biofilm agents. AMB Express 3, 35.

Schillaci, D., Vitale, M., Cusimano, M.G., Arizza, V., 2012. Fragments of $\beta$-thymosin from the sea urchin Paracentrotus lividus as potential antimicrobial peptides against staphylococcal biofilms. Annals New York Acad Sci 1270, 79-85. 
Scocchi, M., Zelezetsky, I., Benincasa, M., Gennaro, R., Mazzoli, A., Tossi, A., 2005. Structural aspects and biological properties of the cathelicidin PMAP-36. FEBS J 272, 4398-4406.

Scott, M.G., Gold, M.R., Hancock, R.E.W., 1999. Interaction of cationic peptides with lipoteichoic acid and gram-positive bacteria. Infect Immun 67, 6445-6453.

Selsted, M.E., Ouellette, A.J., 2005. Mammalian defensins in the antimicrobial immune response. Nat Immunol 6, 551-557.

Shah, M., Brown, K.M., Smith, L.C., 2003. The gene encoding the sea urchin complement protein, $\mathrm{SpC} 3$, is expressed in embryos and can be upregulated by bacteria. Dev Comp Immunol 27, 529-538.

Shai, Y., 1999. Mechanism of the binding, insertion and destabilization of phospholipid bilayer membranes by alpha-helical antimicrobial and cell non-selective membrane-lytic peptides. Biochim Biophys Acta 1462, 55-70.

Shi, J.S., Ross, C.R., Leto, T.L., Blecha, F., 1996. PR-39, a proline-rich antibacterial peptide that inhibits phagocyte NADPH oxidase activity by binding to Src homology 3 domains of p47(phox). Proc Natl Acad Sci U S A 93, 6014-6018.

Shimizu, M., Kohno, S., Kagawa, H., Ichise, N., 1999. Lytic activity and biochemical properties of lysozyme in the coelomic fluid of the sea urchin strongylocentrotus intermedius. J Invertebr Pathol 73, 214-222.

Shin, Y.P., Park, H.J., Shin, S.H., Lee, Y.S., Park, S., Jo, S., Lee, Y.H., Lee, I.H., 2010. Antimicrobial activity of a halocidin-derived peptide resistant to attacks by proteases. Antimicrob Agents Chemother 54, 2855-2866.

Shinnar, A.E., Butler, K.L., Park, H.J., 2003. Cathelicidin family of antimicrobial peptides: proteolytic processing and protease resistance. Bioorg Chem 31, 425-436.

Silva, J.R., 2000. The onset of phagocytosis and identity in the embryo of Lytechinus variegatus. Dev Comp Immunol 24, 733-739.

Silvestro, L., Gupta, K., Weiser, J.N., Axelsen, P.H., 1997. The concentration-dependent membrane activity of cecropin A. Biochemistry 36, 11452-11460.

Smith, L.C. 2012. Innate immune complexity in the purple sea urchin: diversity of the Sp185/333 system. Front Immunol 3, 70.

Smith, L.C., Clow, L.A., Terwilliger, D.P., 2001. The ancestral complement system in sea urchins. Immunol Rev 180, 16-34.

Smith, L.C., Davidson, E.H., 1992. The Echinoid Immune-System and the Phylogenetic Occurrence of Immune-Mechanisms in Deuterostomes. Immunol Today 13, 356-362.

Smith, L.C., Ghosh, J., Buckley, K.M., Clow, L.A., Dheilly, N.M., Haug, T., Henson, J.H., Li, C., Lun, C.M., Majeske, A.J., Matranga, V., Nair, S.V., Rast, J.P., Raftos, D.A., Roth, M., Sacchi, S., Schrankel, C.S., Stensvåg, K., 2010. Echinoderm immunity. Invertebr Immun 708, 260-301.

Smith, L.C., Rast, J.P., Brockton, V., Terwilliger, D.P., Nair, S.V., Buckley, K.M., Majeske, A.J., 2006. The sea urchin immune system. Invertebr Survival J 3, 25-39.

Sodergren, E., Weinstock, G.M., Davidson, E.H., Cameron, R.A., Gibbs, R.A., Angerer, R.C., Angerer, L.M., Arnone, M.I., Burgess, D.R., Burke, R.D., Coffman, J.A., Dean, M., Elphick, M.R., Ettensohn, C.A., Foltz, K.R., Hamdoun, A., Hynes, R.O., Klein, W.H., Marzluff, W., Mcclay, D.R., Morris, R.L., Mushegian, A., Rast, J.P., Smith, L.C., Thorndyke, M.C., Vacquier, V.D., Wessel, G.M., Wray, G., Zhang, L., Elsik, C.G., Ermolaeva, O., Hlavina, W., Hofmann, G., Kitts, P., Landrum, M.J., Mackey, A.J., Maglott, D., Panopoulou, G., Poustka, A.J., Pruitt, K., Sapojnikov, V., Song, X., Souvorov, A., Solovyev, V., Wei, Z., Whittaker, C.A., Worley, K., Durbin, K.J., Shen, Y., Fedrigo, O., Garfield, D., Haygood, R., Primus, A., Satija, R., Severson, T., Gonzalez-Garay, M.L., Jackson, A.R., Milosavljevic, A., Tong, M., Killian, C.E., Livingston, B.T., Wilt, F.H., 
Adams, N., Belle, R., Carbonneau, S., Cheung, R., Cormier, P., Cosson, B., Croce, J. Fernandez-Guerra, A., Geneviere, A.M. Goel, M., Kelkar, H., Morales, J., MulnerLorillon, O., Robertson, A.J., Goldstone, J.V., Cole, B., Epel, D., Gold, B., Hahn, M.E., Howard-Ashby, M., Scally, M., Stegeman, J.J., Allgood, E.L., Cool, J., Judkins, K.M. Mccafferty, S.S., Musante, A.M., Obar, R.A., Rawson, A.P., Rossetti, B.J., Gibbons, I.R., Hoffman, M.P., Leone, A., Istrail, S., Materna, S.C., Samanta, M.P., Stolc, V., Tongprasit, W., Tu, Q., Bergeron, K.F., Brandhorst, B.P., Whittle, J., Berney, K., Bottjer, D.J., Calestani, C., Peterson, K., Chow, E., Yuan, Q.A., Elhaik, E., Graur, D., Reese, J.T., Bosdet, I., Heesun, S., Marra, M.A., Schein, J., Anderson, M.K., Brockton, V., Buckley, K.M., Cohen, A.H., Fugmann, S.D., Hibino, T., Loza-Coll, M., Majeske, A.J., Messier, C., Nair, S.V., Pancer, Z., Terwilliger, D.P., Agca, C., Arboleda, E., Chen, N., Churcher, A.M., Hallbook, F., Humphrey, G.W., Idris, M.M., Kiyama, T., Liang, S., Mellott, D., Mu, X., Murray, G., Olinski, R.P., Raible, F., Rowe, M., Taylor, J.S., Tessmar-Raible, K., Wang, D., Wilson, K.H., Yaguchi, S., Gaasterland, T., Galindo, B.E., Gunaratne, H.J., Juliano, C., Kinukawa, M., Moy, G.W., Neill, A.T., Nomura, M., Raisch, M., Reade, A., Roux, M.M., Song, J.L., Su, Y.-H., Townley, I.K., Voronina, E., Wong, J.L., Amore, G., Branno, M., Brown, E.R., Cavalieri, V., Duboc, V., Duloquin, L., Flytzanis, C., Gache, C., Lapraz, F., Lepage, T., Locascio, A., Martinez, P., Matassi, G., Matranga, V., Range, R., Rizzo, F., Rottinger, E., Beane, W., Bradham, C., Byrum, C., Glenn, T., Hussain, S., Manning, G., Miranda, E., Thomason, R., Walton, K., Wikramanayke, A., Wu, S.-Y., Xu, R., Brown, C.T., Chen, L., Gray, R.F., Lee, P.Y., Nam, J., Oliveri, P., Smith, J., Muzny, D., Bell, S., Chacko, J., Cree, A., Curry, S., Davis, C., Dinh, H., Dugan-Rocha, S., Fowler, J., Gill, R., Hamilton, C., Hernandez, J., Hines, S., Hume, J., Jackson, L., Jolivet, A., Kovar, C., Lee, S., Lewis, L., Miner, G., Morgan, M., Nazareth, L.V., Okwuonu, G., Parker, D., Pu, L.-L., Thorn, R., Wright, R., 2006. The genome of the sea urchin Strongylocentrotus purpuratus. Science 314, 941-952.

Stabili, L., Licciano, M., Pagliara, P., 1994. Evidence of antibacterial and lysozyme like activity in different planktonic larval stages of Paracentrotus lividus. Mar Biol 119, 501-505.

Subbalakshmi, C., Sitaram, N., 1998. Mechanism of antimicrobial action of indolicidin. FEMS Microbiol Lett 160, 91-96.

Tasiemski, A., Schikorski, D., Le Marrec-Croq, F., Pontoire-Van Camp, C., Boidin-Wichlacz, C., Sautiere, P.E., 2007. Hedistin: A novel antimicrobial peptide containing bromotryptophan constitutively expressed in the NK cells-like of the marine annelid, Nereis diversicolor. Dev Comp Immunol 31, 749-762.

Taylor, S.W., Craig, A.G., Fischer, W.H., Park, M., Lehrer, R.I., 2000. Styelin D, an extensively modified antimicrobial peptide from ascidian hemocytes. J Biol Chem 275, 38417-38426.

Terwilliger, D.P., Buckley, K.M., Brockton, V., Ritter, N.J., Smith, L.C., 2007. Distinctive expression patterns of 185/333 genes in the purple sea urchin, Strongylocentrotus purpuratus: an unexpectedly diverse family of transcripts in response to LPS, beta-1,3glucan, and dsRNA. BMC Mol Biol 8, 16.

Terwilliger, D.P., Buckley, K.M., Mehta, D., Moorjani, P.G., Smith, L.C., 2006. Unexpected diversity displayed in cDNAs expressed by the immune cells of the purple sea urchin, Strongylocentrotus purpuratus. Physiol Genomics 26, 134-144.

Uzzell, T., Stolzenberg, E.D., Shinnar, A.E., Zasloff, M., 2003. Hagfish intestinal antimicrobial peptides are ancient cathelicidins. Peptides 24, 1655-1667.

Vasudevan, S., Yuan, J., Ösapay, G., Tran, P., Tai, K., Liang, W., Kumar, V., Selsted, M.E., Cocco, M.J., 2008. Synthesis, structure, and activities of an oral mucosal $\alpha$-defensin from Rhesus macaque. J Biol Chem 283, 35869-35877. 
Veldhuizen, E.J., Schneider, V.A., Agustiandari, H., van Dijk, A., Tjeerdsma-van Bokhoven, J.L., Bikker, F.J., Haagsman, H.P., 2014. Antimicrobial and immunomodulatory activities of PR-39 derived peptides. Plos One 9, e95939.

Wang, G., 2012. Post-translational modifications of natural antimicrobial peptides and strategies for peptide engineering. Current biotechnology 1, 72-79.

Wang, G., Li, X., Wang, Z., 2009. APD2: the updated antimicrobial peptide database and its application in peptide design. Nucleic Acids Res 37, D933-937.

Wu, Y., He, K., Ludtke, S.J., Huang, H.W., 1995. X-ray diffraction study of lipid bilayer membranes interacting with amphiphilic helical peptides: diphytanoyl phosphatidylcholine with alamethicin at low concentrations. Biophys J 68, 2361-2369.

Yang, L., Harroun, T.A., Weiss, T.M., Ding, L., Huang, H.W., 2001. Barrel-stave model or toroidal model? A case study on melittin pores. Biophys J 81, 1475-1485.

Yeaman, M.R., Yount, N.Y., 2003. Mechanisms of antimicrobial peptide action and resistance. Pharmacol Rev 55, 27-55.

Yomogida, S., Nagaoka, I., Yamashita, T., 1996. Purification of the 11- and 5-kDa antibacterial polypeptides from guinea pig neutrophils. Archives Biochem Biophys 328, 219-226.

Yonezawa, A., Kuwahara, J., Fujii, N., Sugiura, Y., 1992. Binding of tachyplesin I to DNA revealed by footprinting analysis: significant contribution of secondary structure to DNA binding and implication for biological action. Biochemistry 31, 2998-3004.

Yui, M.A., Bayne, C.J., 1983. Echinoderm immunology: bacterial clearance by the sea urchin Strongylocentrotus purpuratus. Biol Bull 165, 473-486.

Zasloff, M., 2002. Antimicrobial peptides of multicellular organisms. Nature 415, 389-395.

Zhao, H.X., Mattila, J.P., Holopainen, J.M., Kinnunen, P.K.J., 2001. Comparison of the membrane association of two antimicrobial peptides, magainin 2 and indolicidin. Biophys J 81, 2979-2991. 